HESPERIA $72(2003)$

Pages 447-466

\section{A PERSONIFICATION OF DEMOS ON A NEW ATTIC DOCUMENT RELIEF}

1. The two most thorough and recent studies of the genre are by Meyer (1989) and Lawton (1995a).

2. Hamdorf 1964; TzachouAlexandri 1993, 1994; Lawton 1993; 1995a, pp. 55-59; Smith 1997. For these civic personifications, see also LIMC III, 1986, pp. 145-147, s.v. Boule (V. Komninos); LIMC III, 1986, pp. 372-374, s.v. Demokratia, and pp. 375-382, s.v. Demos (O. TzachouAlexandri); LIMC IV, 1988, p. 120, s.v. Eutaxia (O. Palagia). A new study of political personifications in Classical and Hellenistic art by Messerschmidt (2003) appeared too late for me to consult for the text of this article, but I have included the relevant data in the appendix. I would like to thank Kristen Seaman for this reference.

3. Lawton 1995a, pp. 1-4.

\begin{abstract}
This article presents a previously unpublished document relief discovered during excavations on the north slope of the Acropolis of Athens in 1937. Although fragmentary, this relief contributes to the corpus of 4th-century в.c. document reliefs by providing a well-preserved depiction of what is most likely "Demos," the personification of the Athenian people, awarding a crown to a mortal man. The iconography of Demos is reviewed and an appendix presents a list and concordance of all extant representations of Demos on Attic document reliefs.
\end{abstract}

Document reliefs combine figural decoration with the official text of public records such as decrees, laws, treaties, cult regulations, and inventories, and thus represent an important class of evidence for the study of ancient Greek art, history, and politics. ${ }^{1}$ Close examination of the iconography and historical context of Attic document reliefs from the Classical and Hellenistic periods has demonstrated how this unique body of securely dated, original Greek sculpture can provide new insights into the relationship of the visual arts and political ideology in ancient Athens. For example, document reliefs have been crucial in our understanding of the use and development of allegorical figures in Athenian public art, in particular the personification of local and foreign places (e.g., Salamis, Messana), abstract qualities such as Demokratia (Democracy) and Eutaxia (Good Order), and civic institutions such as Demos (the People) and Boule (the Council). ${ }^{2}$

Most of the known Attic document reliefs were first discovered during the excavations of the Athenian Acropolis in the 19th century. ${ }^{3}$ Others were found on the south slope, a few in the Agora, and a few elsewhere. While excavations in Athens still have the potential to bring to light future discoveries of document reliefs and their inscriptions, a careful examination of unpublished material from older projects-in a sense, the "excavation" of storerooms - can also provide important new evidence for the study of this genre. It is in this context that I present an Attic document relief recently identified among the sculptural fragments from the excavations on the north slope of the Acropolis conducted by Oscar Broneer 
and the American School of Classical Studies at Athens prior to World War II. As with the examples found elsewhere on the slopes of the citadel, it is most likely that this monument originally stood within a sanctuary on the Acropolis itself and made its way down to the north slope at some later time. Although the fragment does not preserve the text of the document that it crowned, it contributes to the corpus of Attic reliefs by providing a relatively well preserved depiction of a figure who is most likely Demos, the personification of the Athenian people.

\section{THE RELIEF}

Relief from an honorary decree depicting Demos(?) crowning an honorand. Athens, Agora Museum Storeroom AS 146. Third to fourth quarter of the 4th century в.с.

Figs. 1-3

P.H. 0.378; p.W. 0.218; Th. 0.118; H. of relief 0.015 m.

Found May 28, 1937, built into a "late" (probably Ottoman period) wall within the cleft of the Mycenaean Fountain, near the eastern entrance. ${ }^{4}$ Preserved is the right half and top of the relief. Broken at the bottom and on the left side. The back is roughly finished with a large, pointed chisel. The relief was bordered at right by an anta $(0.035 \mathrm{~m}$ wide), now mostly chipped away but preserved as a slightly raised edge on the background. The right side of the stone is finished flat with a fine-toothed chisel. Above the relief field is an entablature crowned with antefixes, now worn and chipped. The surface is worn and there is some mineral encrustation and traces of mortar on the background and break surfaces. Fine-grained, white marble with micaceous streaks and light reddish-tan patina (Pentelic).

None of the inscription is preserved, but the subject of the relief indicates that it once decorated an honorary decree. The relief depicts a small male figure being awarded a crown by a larger male figure at right. The honorand, whose entire left side is preserved to approximately knee level, stands in a completely frontal pose, wearing a long himation wrapped around his waist and draped over his left shoulder and arm. His left arm is bent at his waist, and part of his hand is preserved emerging from the himation. His hair is worn short and has the appearance of curls. His beard is also full, but his lower lip is clearly articulated within the mass of facial hair. His eyes are deeply set, even at such a small scale and in this frontal view, and are framed by thick eyelids (Fig. 2).

At right stands a mature male figure at a much larger scale, obviously intended to represent a divinity or personification. This larger figure is completely preserved except for the feet, which are broken at the ankles. The figure stands frontally with his weight on his left leg, and his left hip is correspondingly slightly raised. The right leg is free and the knee is bent inward toward the left leg. The left foot appears to have been mostly frontal, while the outline of the broken right foot reveals that it was in threequarter view to left with the heel slightly raised. Like the honorand, this larger figure wears a long himation wrapped around his waist and thrown over his left shoulder, while his chest is bare. The himation is folded at the waist and falls diagonally from left to right toward the weight-bearing leg.
4. For the 1937 excavations on the north slope, see Broneer 1938a, 1938b. The entrance to the Mycenaean Fountain was erroneously called at that time the "Aglaureion" or "Cave of Aglauros." The wall in which the relief was found is partially visible in a photograph taken in 1934 prior to excavation. See Broneer 1939, p. 323, fig. 3. 
Figure 1. Athens, Agora Museum AS 146. Relief from an honorary decree. Demos(?) crowning honorand. Third to fourth quarter of the 4th century B.c. Courtesy Agora Excavations, photo C. Mauzy

Figure 2 (left). Athens, Agora Museum AS 146. Detail of head of honorand. Courtesy Agora Excavations, photo C. Mauzy

Figure 3 (right). Athens, Agora Museum AS 146. Detail of head of Demos(?). Courtesy Agora Excavations, photo C. Mauzy
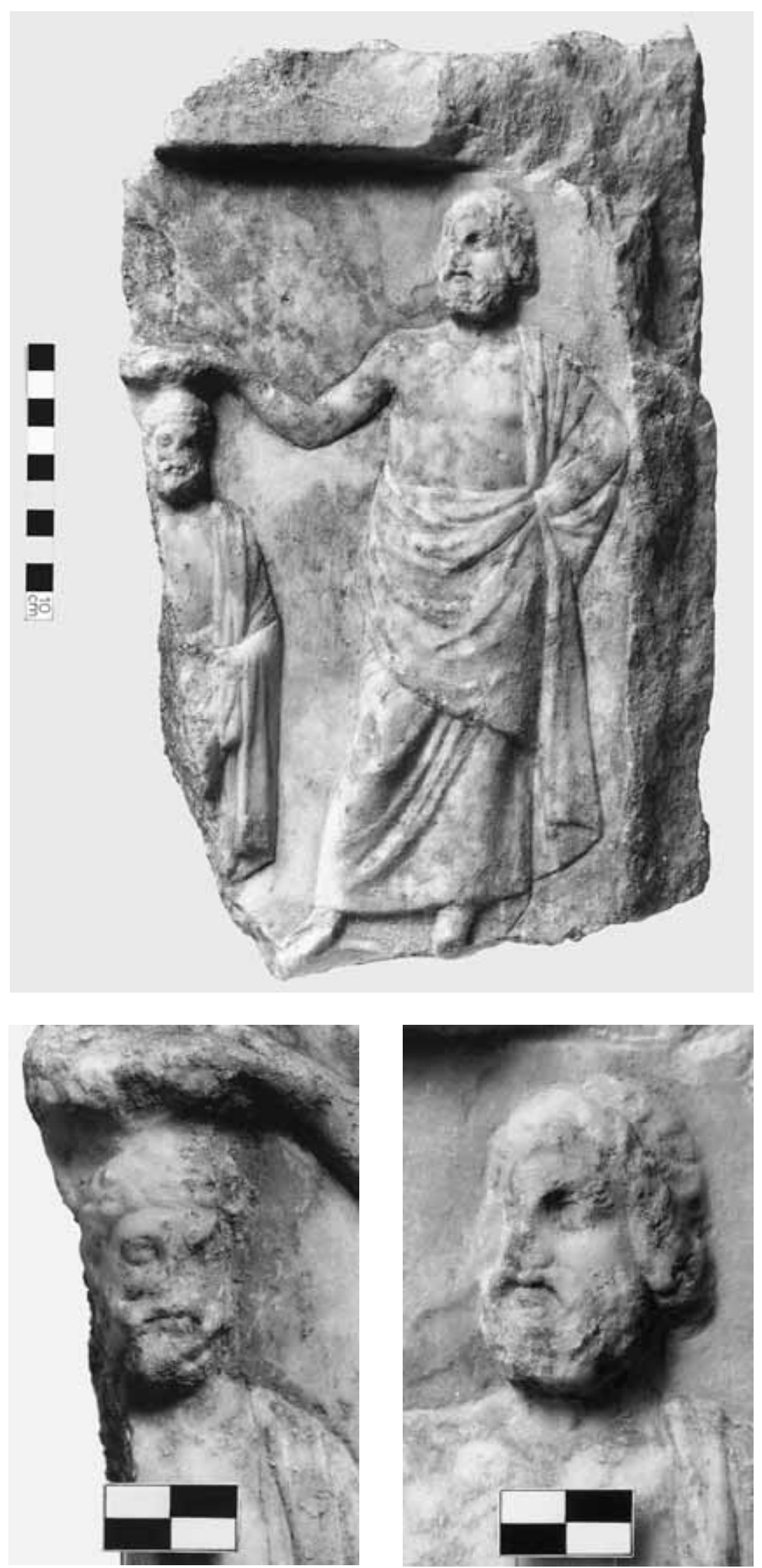
The figure's left arm is bent and is completely covered by the garment, with the hand resting on the hip but held slightly behind the body. His right arm is raised and his hand is extended to hold a crown over the head of the honorand.

The head of the larger figure is shown in three-quarter view to left, glancing in the direction of the mortal being crowned (Fig. 3). His hair is full and covers his ears but does not reach down to the shoulders. The rendering of the hair into two separate masses at front and back suggests that he wore a fillet around his head, once probably picked out with paint. He has a thick, bushy beard, and his lower lip is fully formed within a deep recess between beard and moustache. His eyes are deeply set and framed with overhanging brows, and the eyelids are carefully articulated.

\section{DISCUSSION}

On the basis of parallels with other Athenian honorary reliefs, the larger male figure in this relief probably represents Demos, the physical embodiment of the Athenian people and state as well as the representation of the citizen body (the ekklesia, or assembly) that enacted the decree recorded in the now missing inscription. In this dual role, Demos appears as one of the most common civic personifications in Athenian document reliefs. ${ }^{5} \mathrm{He}$ is consistently represented as a mature male figure, bearded, with medium to long hair frequently bound by a fillet. He wears a long himation over his left shoulder but is otherwise nude to the waist. ${ }^{6} \mathrm{He}$ can be shown seated or standing, sometimes carrying or leaning on a staff. His overall appearance is very similar to that of Asklepios and Zeus, and may have even been modeled, to some degree, on representations of those two divinities in freestanding and relief sculpture. ${ }^{7} \mathrm{He}$ also recalls some of the standing/ leaning "Eponymous Heroes" and marshals on the Parthenon frieze, who themselves evoke the typical elder citizens of Athens. As noted by several scholars, it may have been an important part of the characterization of Demos in the visual arts to resemble, but on a larger scale, the citizens he personifies. $^{8}$

A cult of Demos existed in Athens at least as early as the mid-5th century, and the personified Demos appears as a character in the Knights of Aristophanes, performed in 424 в.с. ${ }^{9}$ The earliest-attested depiction of Demos in ancient art, however, is a monumental painting by Parrhasios (last quarter of the 5 th century). ${ }^{10}$ Later are paintings by Euphranor (mid-

\footnotetext{
5. For the various and complex meanings of the personified Demos on document reliefs, see Lawton 1995a, pp. 55-56; Smith 1997, pp. 76-78, 174-177.

6. LIMC III, 1986, p. 381, s.v. Demos (O. Tzachou-Alexandri); Palagia 1980, pp. 57-59; Tzachou-Alexandri 1994; Lawton 1995a, pp. 56-58; Smith 1997, pp. 174-177.

7. On the similarity of the various
}

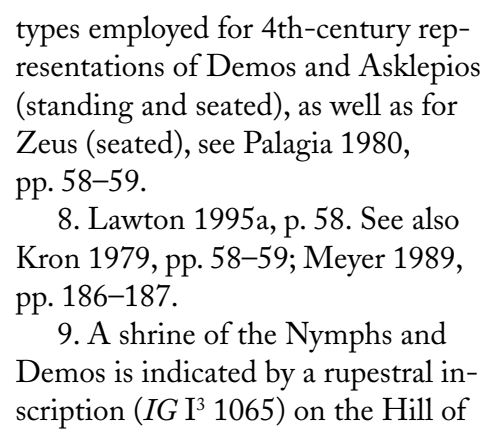

the Nymphs, west of the Agora. See Kron 1979, pp. 63-75; LIMC III, 1986, pp. 375-376, s.v. Demos (O. TzachouAlexandri).

10. Painting of Demos by Parrhasios: Plin. HN 35.69; Rumpf 1951, pp. 7-10; Hamdorf 1964, p. 31, no. 255a; Palagia 1980, pp. 59-61, no. B1; LIMC III, 1986, p. 379, no. 47, s.v. Demos (O. Tzachou-Alexandri); Smith 1997, p. 237, no. MP3. 
Figure 4. Athens, Epigraphical Museum 2791 ( $\left.I G \mathrm{II}^{2} 160\right)$. Demos and honorand. Mid-4th century в.с. Courtesy Museum
11. Painting of Theseus, Demos, and Demokratia by Euphranor: Paus. 1.3.3-4; Agora III, p. 27, no. 30; Hamdorf 1964, p. 94, no. 255b, 112, no. 448b; Palagia 1980, pp. 57-60; LIMC III, 1986, p. 379, no. 48, s.v. Demos (O. Tzachou-Alexandri); Smith 1997, p. 239, no. MP7.

Painting of Demos by Aristolaos: Plin. HN 35.137; EAA I, 1958, pp. 648-649, s.v. Aristolaos (F. Magi); Hamdorf 1964, pp. 31-32, no. 255c; Palagia 1980, p. 61, no. B2.

12. Statue of Demos by Leochares: Paus. 1.1.3; Hamdorf 1964, p. 94,

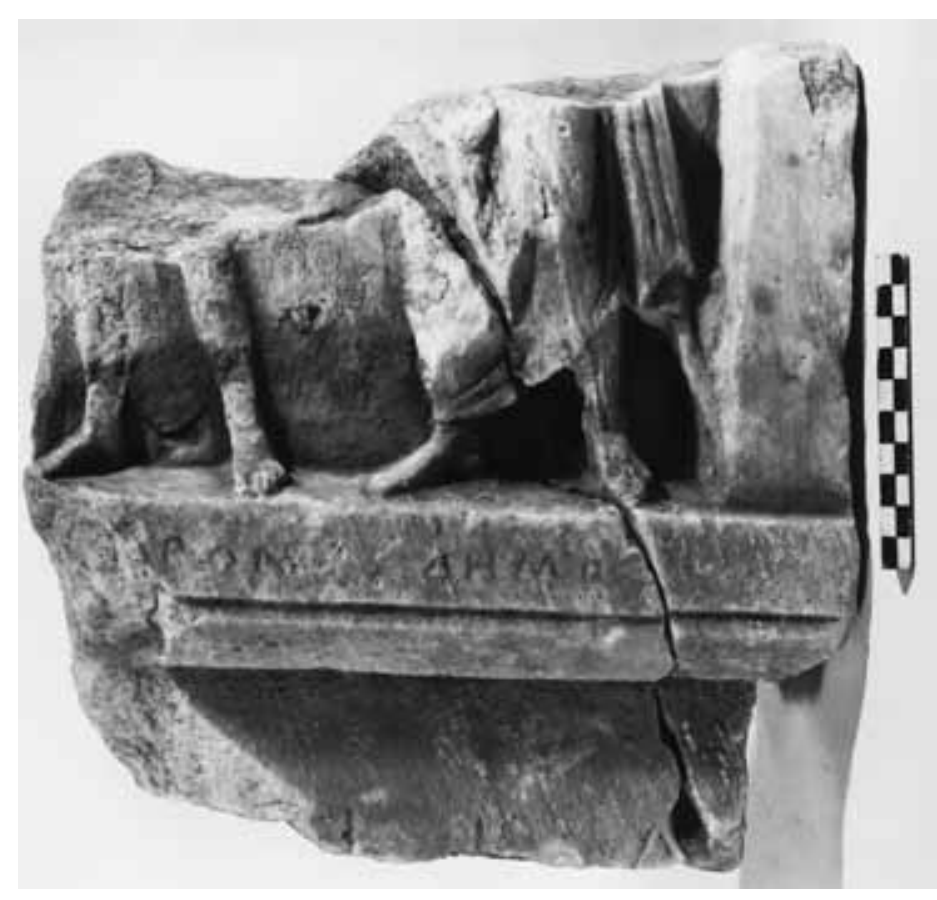

4th century) and Aristolaos (mid- to second half of the 4th century). ${ }^{11}$ Ancient sources also mention a statue of Demos by Leochares (mid-4th century) in the Piraeus, a resolution authorizing the creation of a colossal group of the Demos of Athens being crowned by the Demoi of Byzantion and Perinthos (4th century), and a bronze statue in the Bouleuterion of Athens by Lyson (date uncertain). ${ }^{12}$ Since these paintings and sculptures are now lost, their influence on contemporary and later art cannot be accurately determined and must remain a matter for speculation.

The earliest securely identified and preserved depictions of the personified Demos, therefore, are to be found on document reliefs. Three representations of Demos, attested by inscribed labels, help to establish the two main figural types (standing and seated) in which this important personification is portrayed. The earliest is on a fragmentary honorary decree (EM 2791; Fig. 4) of the mid-4th century в.c. ${ }^{13}$ Here Demos is shown as a standing male figure wearing a himation and holding a staff.

no. 253a; Palagia 1980, p. 61, no. C1; LIMC III, 1986, p. 377, no. 8, s.v.

Demos (O. Tzachou-Alexandri); Smith 1997, p. 267, no. S7.

Colossal group of the Demoi of Athens, Byzantion, and Perinthos: Dem. 18.90; Hamdorf 1964, p. 94, nos. 253b, 256; Palagia 1980, p. 61, no. C2; LIMC III, 1986, p. 378, no. 36, s.v. Demos (O. Tzachou-Alexandri); Smith 1997, p. 270, no. S13.

Statue by Lyson: Paus. 1.3.5; Agora III, pp. 131-132, no. 402; EAA IV, 1961, p. 753, s.v. Lyson (G. Mansuelli); Palagia 1980, pp. 61-62, no. C3. A late source (Gnomologium Vaticanum 339b) mentioning a statue of Demos "without ears" by the 4th-century sculptor Lysippos is suspect and should not be confused with this work by Lyson.

13. Athens, Epigraphical Museum 2791. Provenance unknown. $I G \mathrm{II}^{2}$ 160; Palagia 1980, p. 62, no. D9; LIMC III, 1986, p. 381, no. 69, s.v. Demos (O. Tzachou-Alexandri); Meyer 1989, p. 307, no. A146, pl. 40:2; TzachouAlexandri 1994, p. 67; Lawton 1995a, p. 133 , no. 117 , pl. 61 ; Smith 1997 , p. 213, no. DR22. 


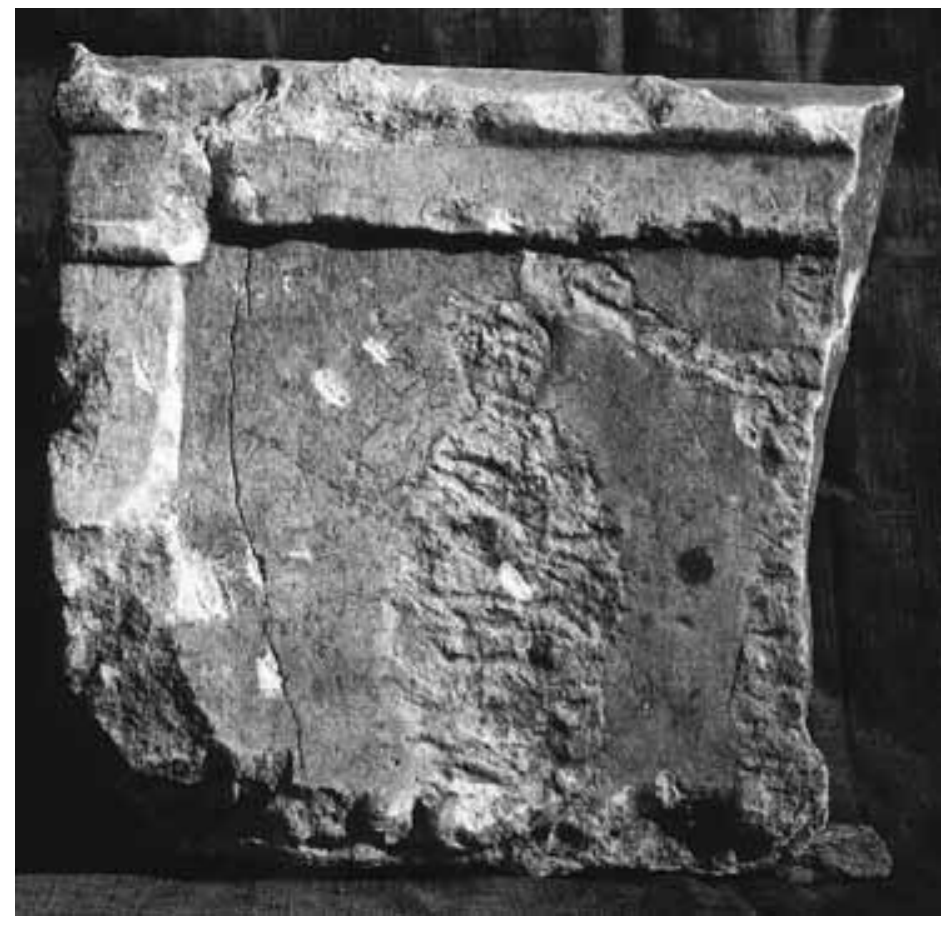

Figure 5. Athens, National Archaeological Museum 7272. Demos (of Aixone?) crowns honorand. Second half of the 4th century в.c. Courtesy Deutsches Archäologisches Institut, Athens; photo H. Wagner, neg. Attika 202

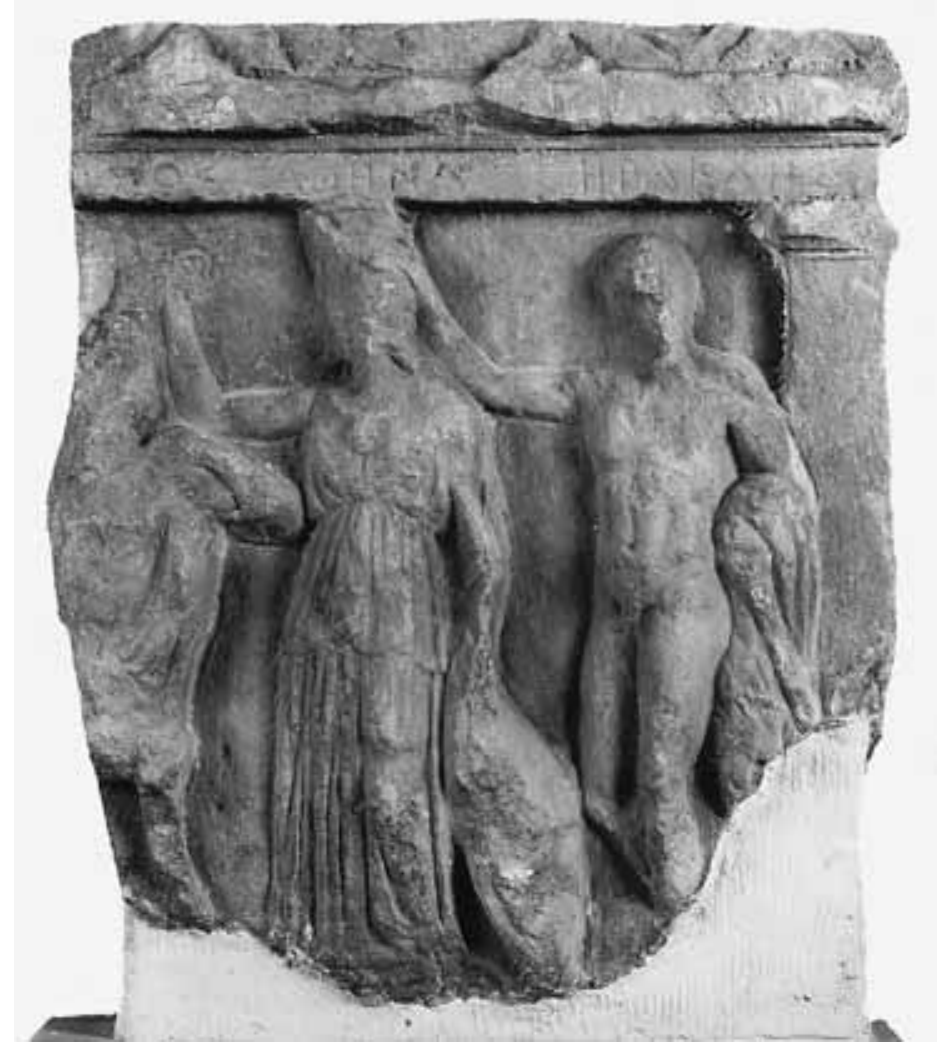

Figure 6. Athens, National Archaeological Museum 2407 ( $I G \mathrm{II}^{2}$ 4630). Demos, Athena, and Herakles.

Third quarter of the 4th century B.c. Courtesy Museum 
Although only the legs and feet of the figure are preserved, the mass of drapery hanging down along his left side (i.e., the "open" side of the garment) suggests that the himation was worn over the left shoulder. He is apparently crowning an honorand standing to left and depicted, as usual, at a much smaller scale. The names of both the mortal $([---] \Delta \mathrm{P} \Omega \mathrm{N})$ and the personification $(\triangle H M O \Sigma)$ are clearly inscribed on the taenia of the molding beneath the relief. ${ }^{14}$ It has been suggested, on the basis of both the space required to restore the first line of the inscription and by comparison with similar reliefs, that another figure, either Athena or Boule, may have been depicted to the left of the honorand.

The second relief (NM 7272; Fig. 5), also on an honorary decree (second half of the 4th century), has been badly damaged by having the figures systematically picked away. ${ }^{15}$ Enough is preserved of the outline of the figures, however, to identify the scene as a large divinity or personification reaching up with his left hand to crown a mortal. The identification of the larger figure as Demos is based upon an inscription on the architrave immediately above his head $(\Delta \mathrm{H}[\mathrm{MO} \Sigma])$. Since the relief was found in modern Trachones, however, it has been suggested that the figure represents the personification of the Demos of a nearby deme, probably Aixone, and not the Demos of Athens itself. ${ }^{16}$

The third relief (NM 2407; Fig. 6), from an honorary decree(?) of the third quarter of the 4th century, depicts Demos as a mature, bearded man seated to left, presumably facing an honorand, now missing. ${ }^{17}$ His torso is turned in three-quarter view and his left arm is propped up on the back of his chair. He also wears a himation around his waist and over his left shoulder. In back of Demos, to right, are Athena and Herakles. All three figures are identified by inscription on the architrave above the scene $([\Delta] \mathrm{HMO} \Sigma$ A $\Theta H N A$ HPAK $\Lambda \mathrm{H} \Sigma$ ).

Even without inscribed labels, the appearance of Demos can be suggested, with varying degrees of probability, on several other reliefs. The strongest argument can perhaps be made for the representation of Demos on the famous anti-tyranny law of $337 / \underline{6}$ в.c. from the Athenian Agora

14. Lawton (1995a, pp. 11-12; 1995 b, p. 122) has noted that the profiled molding below the scene, a regular feature of document reliefs but rare on votive reliefs, helps to distinguish the two types of monuments even when inscriptions or other identifying characteristics are not preserved.

15. Athens, National Museum 7272. From Trachones (Attica). Meyer 1989, p. 314, no. A182, pl. 52:4; Lawton 1995a, p. 155, no. 176, pl. 91; Smith 1997, pp. 224-225, no. DR38.

16. On the depiction of local Demoi and their similarity to the Demos of Athens, see Smith 1997, pp. 172-179. In addition to Athens, National Mu- seum 2407, local Demoi may be represented on Eleusis, Museum E958 ( $I G \mathrm{I}^{3}$ 79; LIMC II, 1984, p. 1013, no. 606, pl. 763, s.v. Athena [P. Demargne]; LIMC III, 1986, pp. 378-379, no. 42, s.v. Demos [O. Tzachou-Alexandri]; Meyer 1989, p. 266, no. A5; Lawton 1995a, pp. 82-83, no. 3, pl. 2; Smith 1997, p. 197, no. DR1) and on a relief in a private collection (St. Lydakis) in Athens (Meyer 1989, p. 299, no. A119, pl. 34:1; Lawton 1995a, p. 145, no. 147, pl. 78; Smith 1997, pp. 230-231, no. DR45).

17. Athens, National Museum 2407. Found near the Church of Ayios Dimitrios Loumbardiaris, between the
Pnyx and the Philopappos Monument. $I G \mathrm{II}^{2}$ 4630; Kron 1979, pp. 49-63, pl. 7:1-2; Palagia 1980, p. 63, no. E4; LIMC III, 1986, p. 379, no. 46, pl. 274, s.v. Demos (O. Tzachou-Alexandri); Meyer 1989, p. 292, no. A94, pl. 28:2; Tzachou-Alexandri 1994, p. 59, fig. 6; Lawton 1995a, p. 139, no. 133, pl. 71; Smith 1997, pp. 216-217, no. DR27.

An older interpretation of the seated figure as the hero Akademos (based upon the conjectural reading [AKA$\triangle$ ]HMO $\Sigma$ ) is considered unlikely. See Kron 1979, p. 58, and LIMC I, 1982, pp. 434-435, no. 2, s.v. Akademos (U. Kron). 


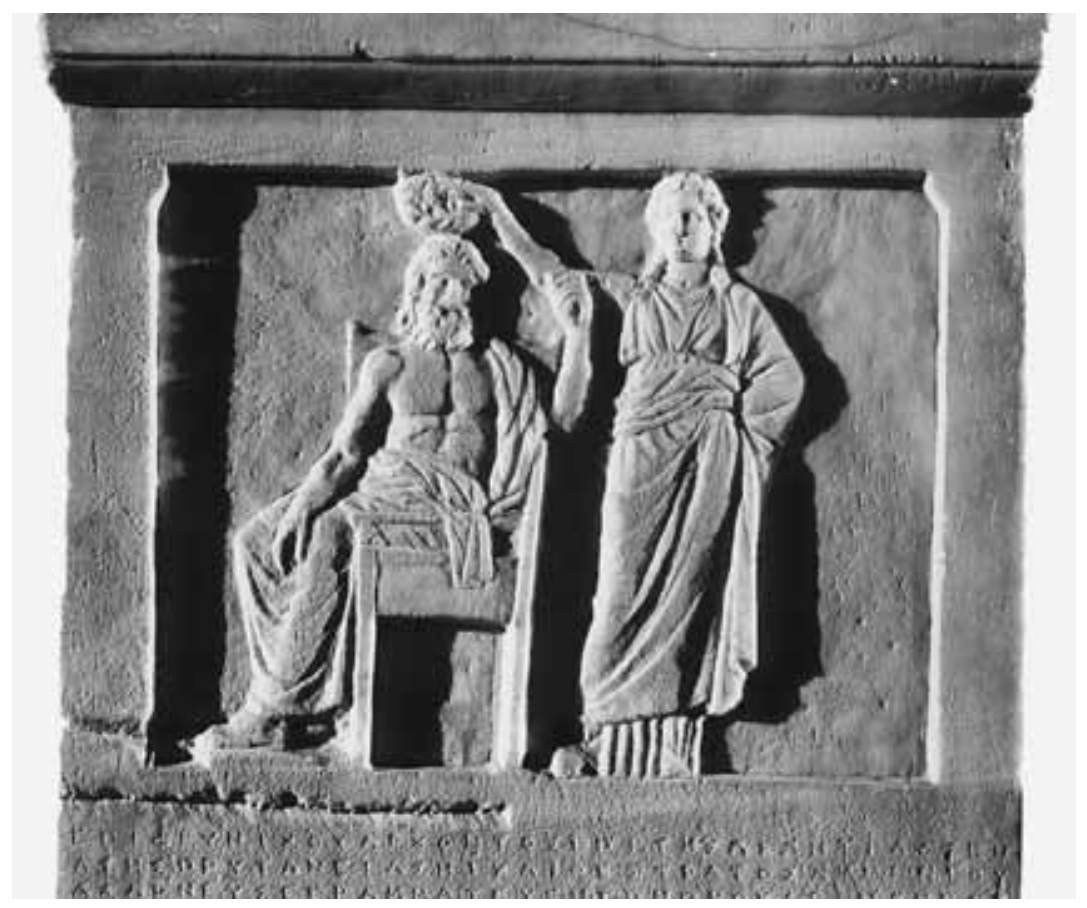

(I 6524; Fig. 7), on which a mature, bearded, and long-haired male figure is seated on a throne. ${ }^{18}$ The pose is comparable to but not identical with that of the seated figure on the previously mentioned relief (NM 2407; Fig. 6). On the Agora relief, Demos sits with his legs in profile to left, while his torso and head are turned frontally. His left arm is raised to the back of his chair, apparently to hold a staff, scepter, or spear (once painted). He wears a himation around his waist and over his left shoulder. Beside him is a standing, frontal, long-haired female who wears a sleeved, highbelted chiton and himation, also wrapped around her waist and draped over her left shoulder. With her right hand she reaches out to offer a crown to the seated male figure. While the identification of the seated male as Demos can be supported by comparisons with the type on other document reliefs, the identity of the female figure is based primarily upon the text of the anti-tyranny law itself, where the "demos of the Athenians" and "democracy in Athens" are specifically mentioned together three times (lines $8-9,13-14,16-17)$. It has been suggested that the depiction, or at least the pairing, of Demos and Demokratia on this relief may have been partially inspired by Euphranor's famous paintings in the Stoa of Zeus Eleutherios in the Agora (Paus. 1.3.3-4), where the two personifications may have been juxtaposed for the first time in the visual arts. ${ }^{19}$

18. Athens, Agora I 6524. SEG XII 87; Meritt 1952, pp. 355-359, no. 5, pls. 89-90; Raubitschek 1962; Agora XIV, pp. 61, n. 173, 102, pl. 53:a; Palagia 1980, p. 63, no. E3, fig. 43; LIMC III, 1986, p. 373, no. 7 , pl. 271, s.v. Demokratia (O. TzachouAlexandri); LIMC III, 1986, p. 379, no. 54, pl. 271, s.v. Demos (O. Tzachou-Alexandri); Meyer 1989, p. 293, no. A97, pl. 30:2; Tzachou-Alexandri 1994, pp. 55-56, fig. 1; Lawton 1995a,
Figure 7. Athens, Agora I 6524 (SEG XII 87). Demos being crowned by Demokratia. 337/ $\underline{6}$ B.c. Courtesy Agora Excavations pp. 99-100, no. 38, pl. 20; Smith 1997, pp. 227-228, no. DR41.

19. Raubitschek 1962, p. 238; Agora XIV, p. 102; Palagia 1980, p. 60; Lawton 1995a, p. 100. Palagia (1980, pp. 58-59) also notes the "indirect ref- 
Figure 8. Athens, National Archaeological Museum $2952+2961$.

Athena and Demos(?) crown two honorands. Mid-third quarter of the 4th century B.c. Courtesy Museum erence" of Demos on this relief to Pheidian prototypes such as the figure of Zeus on the east frieze and possibly also the east pediment of the Parthenon.

20. Lawton (1995a, p. 58) suggests that the personification of Boule may have been invented specifically for document reliefs, and would probably not be depicted in this genre without the presence of Demos. Hence Lawton (1995a, pp. 142-143, no. 142, pl. 75) would restore a figure of Demos on the

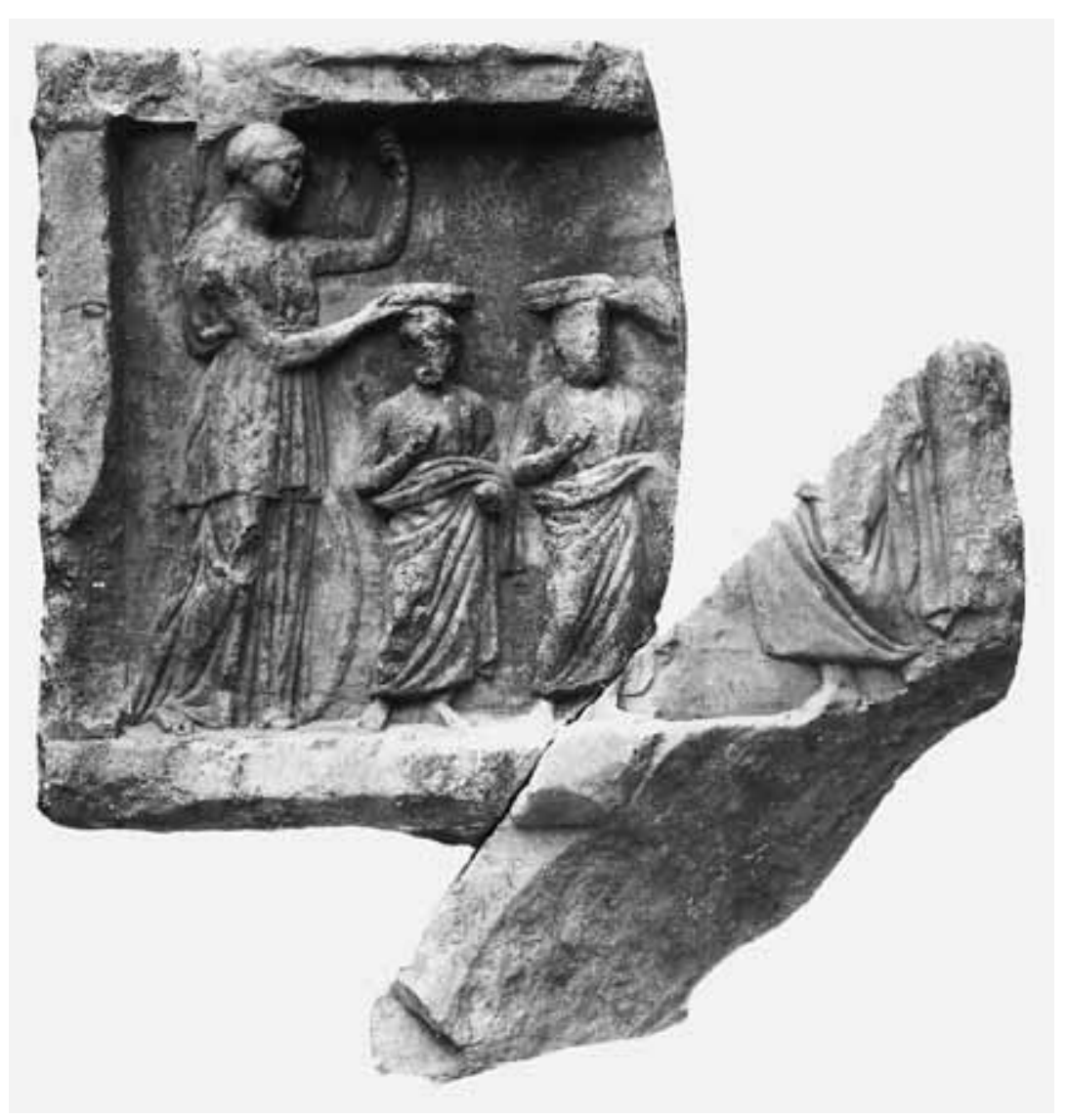

Among the preserved standing male types on other document reliefs, the most convincing identifications are those where Demos is paired with other important figures referring to the Athenian state, such as Athena, Boule, or both. ${ }^{20}$ For example, on NM 2952+2961 (Fig. 8) Athena and a large male figure frame the relief on left and right, respectively, and they crown two frontal honorands standing in the center. ${ }^{21}$ The position of this unlabeled male divinity/personification, of whom only the lower legs and right hand holding the crown are preserved, is reminiscent of the labeled Demos on EM 2791 (Fig. 4). A similar pairing of Athena and Demos may be found on two reliefs decorating honorary decrees, both probably found

now missing right side of a fragmentary document relief (Athens, National $\mathrm{Mu}-$ seum 1473) of the third quarter of the 4th century preserving the figures of Athena and Boule (labeled $\mathrm{BO} \Lambda \mathrm{E}$ ) in the presence of a mortal honorand. On the other hand, Tzachou-Alexandri (1994, pp. 56-57, figs. 2-3) prefers to restore another mortal figure, noting that the preserved honorand, who faces left toward Athena and Boule, would have his back turned toward any hypo- thetical Demos awarding him a crown from the right.

21. Athens, National Museum 2952 + 2961 (mid-third quarter of the 4th century). Provenance unknown. Palagia 1980, p. 62, no. D3; LIMC III, 1986, p. 380 , no. 56 , pl. 275 , s.v. Demos (O. Tzachou-Alexandri); Meyer 1989, p. 292, no. A95, pl. 30:1; TzachouAlexandri 1994, p. 67; Lawton 1995a, pp. 136-137, no. 126, pl. 67; Smith 1997, pp. 217-218, no. DR28. 

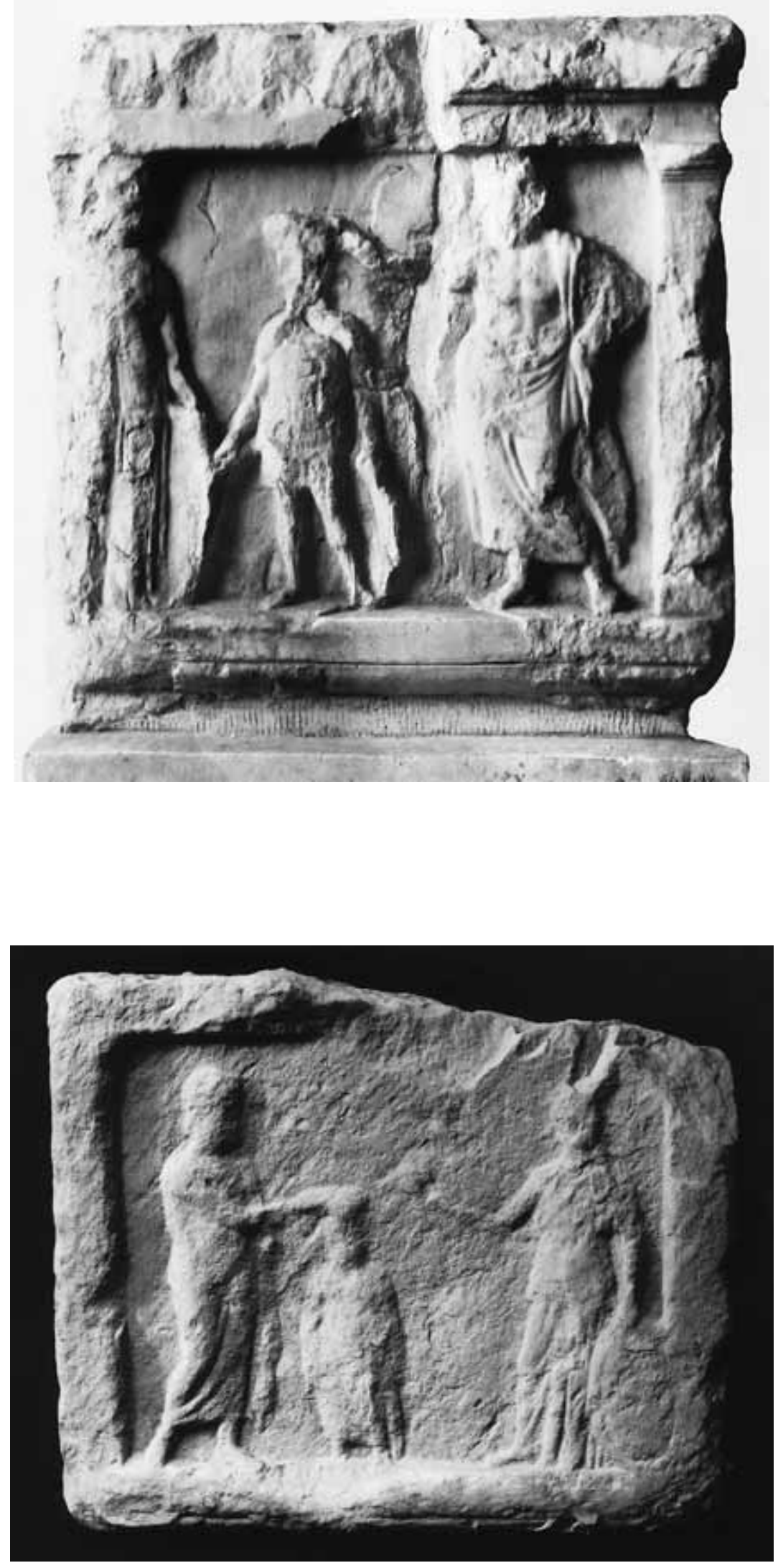

Figure 9. Athens, National Archaeological Museum 2946. Athena observes Demos(?) crowning honorand. Third to fourth quarter of the 4th century B.c. Courtesy Museum
Figure 10. Athens, Acropolis Museum 7231. Demos(?) and Athena crown honorand. Second half of the 4th century B.c. Courtesy Museum 
Figure 11. Athens, National Archaeological Museum 1482 ( $\left.I G \mathrm{II}^{2} 448\right)$. Athena observes as Demos(?) awards crown to Euphron of Sikyon.

31요 7 в.c. Courtesy Museum

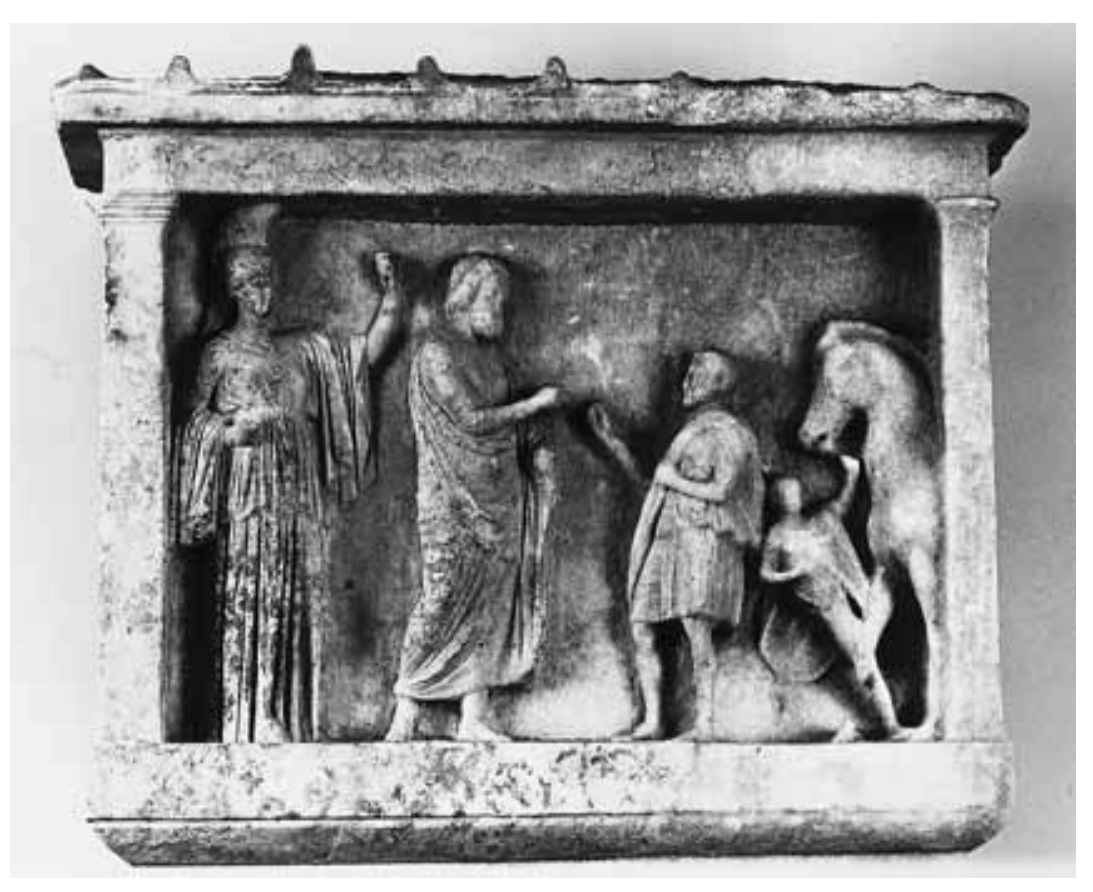

on the Acropolis (NM 2946 and AM 7231; Figs. 9, 10). ${ }^{22}$ In the latter example (AM 7231) the Demos figure has moved to the left side of the relief, while on yet another (NM 1482; Fig. 11), a figure probably to be identified as Demos stands near the center of the composition, directly interacting with the honorand, while Athena observes from behind. ${ }^{23} \mathrm{~A}$ slightly less secure identification of the pair appears on an honorary decree(?) of the mid-third quarter of the 4th century (NM 2986; Fig. 12), with a goddess standing in the central position, a small male figure at right, and Demos at left, in a himation and pose similar to that of the large figure on the north slope relief. ${ }^{24}$ Variations of the Athena-honorand-Demos scheme

$I G \mathrm{II}^{2}$ 448; Palagia 1980, p. 62, no. D7; LIMC III, 1986 , p. 380 , no. 58 , pl. 275 , s.v. Demos (O. Tzachou-Alexandri); Meyer 1989, p. 303, no. A134, pl. 39:1; Tzachou-Alexandri 1994, pp. 66-67, fig. 17; Lawton 1995a, pp. 107-108, no. 54 , pl. 28; Smith 1997 , pp. 232233, no. DR48.

24. Athens, National Museum 2986. From Athens. Tzachou-Alexandri 1994, pp. 59-66, figs. 7-16; Lawton 1995a, pp. 135-136, no. 123, pl. 66; Smith 1997, pp. 218-219, no. DR30. The identity of the female figure, who wears a high-belted peplos and a shoulder mantle, is not immediately clear, since her head is missing and she does not have an aegis, shield, or other distinguishing attribute. Lawton considers her to be Hera, with her left arm raised and possibly holding out her veil in a bridal gesture (anakalypsis). The larger male figure would then represent Zeus holding a (once painted) scepter with his raised right arm. TzachouAlexandri, however, argues that the pair depicts Athena and Demos, pointing out that the goddess's dress, a highbelted peplos with himation draped down her back and over her right arm, is a characteristic costume of Athena. Moreover, the goddess is not always depicted with an aegis or shield, and her identity could have been made clear in other ways, such as by the presence of a helmet on her (now missing) head. Smith observes that the male figure seems to be slightly shorter than the female, a characterization of inferior status more appropriate for Demos than for Zeus.
23. Athens, National Museum 1482
(31의 7 в.c.). Found in the Late Roman fortifications near the Stoa of Attalos. 

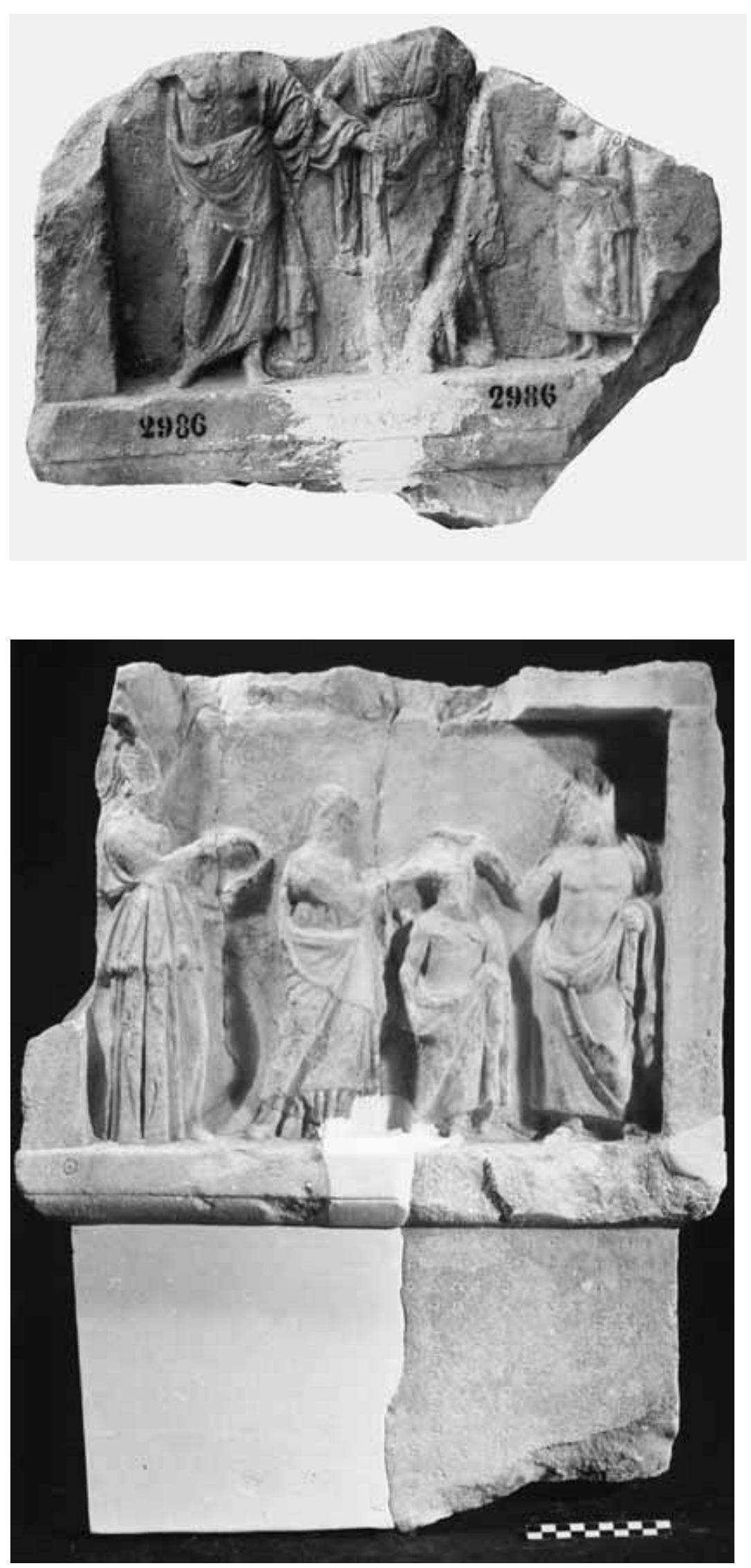

Figure 12. Athens, National Archaeological Museum 2986. Demos/ Zeus(?) and Athena/Hera(?) in presence of honorand. Mid-third quarter of the 4th century. Courtesy Museum
Figure 13. Athens, Epigraphical Museum 2811 + 7180 (IG $\left.\mathrm{II}^{2} 367\right)$. Athena holds crown and observes as Boule(?) and Demos(?) crown Asklepiodoros. 323/2 в.c. Courtesy Museum 
Figure 14. Athens, National Archaeological Museum 2958 (+ EM 7166 = $I G \mathrm{II}^{2} 417$ [?]). Demos(?) crowns honorand (liturgist?) while Eutaxia observes. Fourth quarter of the 4th century. Courtesy Museum
25. Athens, Epigraphical Museum $2811+7180$ (32ㄹ/2 B.C.). From the Acropolis. $I G \mathrm{II}^{2}$ 367; Palagia 1980, p. 62, no. D6; LIMC III, 1986, p. 146, no. 3, s.v. Boule (V. Komninos); LIMC III, 1986, p. 380 , no. 57 , pl. 275, s.v. Demos (O. Tzachou-Alexandri); Meyer 1989, pp. 300-301, no. A125, pl. 35:2;

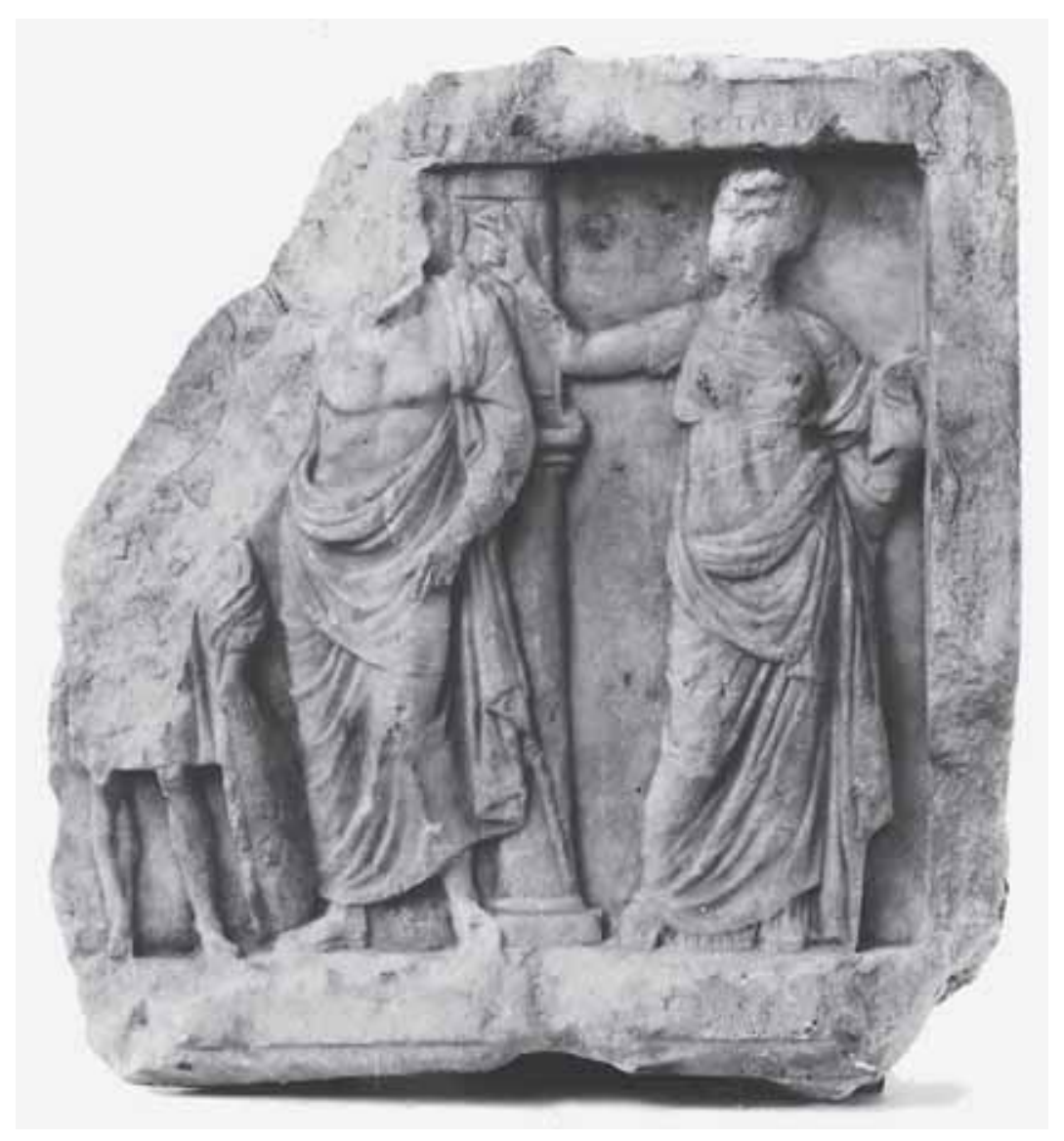

may also include other appropriate personifications, such as Boule (EM $2811+7180$; Fig. 13) or Eutaxia (NM 2958; Fig. 14). ${ }^{25}$

The new fragment from the north slope of the Acropolis, therefore, fits into a well-established iconographic tradition in 4th-century Athens. The crowning of an honorand or honorands, depicted as mortal by their small scale compared with the divinity, hero, or personification bestowing the award, is the most common motif in reliefs decorating honorary decrees, especially those awarded by the boule and demos. ${ }^{26}$ Although there are no inscribed labels on the preserved sections of the north slope relief, the pose, age, dress, and features of the large, supernaturally sized, male figure crowning the mortal honorand all support his identification as Demos, the personification of the Athenian people and government. The frontal stance of the honorand, along with the tall and narrow proportions of the preserved fragment, makes it likely that at least one other largescale divinity or personification was once portrayed on the now-missing left half of the relief.

Lawton 1995a, pp. 105-106, no. 49, pl. 26; Smith 1997, pp. 231-232, no. DR47.

Athens, National Museum 2958 (fourth quarter of the 4th century). From the Acropolis. Possibly belonging with Athens, Epigraphical Museum $7166=I G \mathrm{II}^{2}$ 417(?); Palagia 1980, p. 62 , no. D8, fig. 34 ; LIMC III, 1986 , p. 380 , no. 59 , pl. 275 , s.v. Demos (O. Tzachou-Alexandri); LIMC IV, 1988, p. 120, s.v. Eutaxia (O. Palagia); Meyer 1989, p. 306, no. A142, pl. 42:1; Lawton 1995a, p. 146, no. 150, pl. 79; Smith 1997, pp. 233-234, no. DR49. 26. Lawton 1995a, pp. 30-36. 


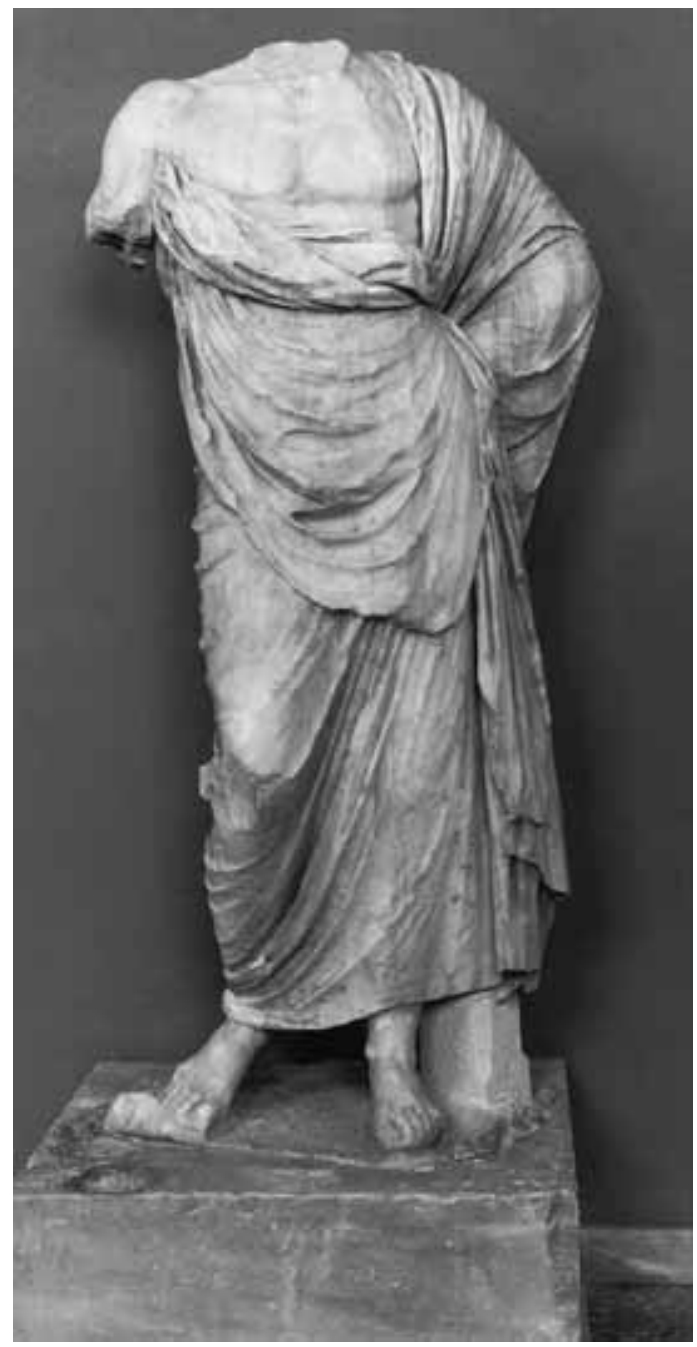

The date of the relief can be estimated by comparison with other dated monuments. The most numerous parallels for the dress and pose of Demos on the north slope relief are found in the second half of the 4th century. In large-scale sculpture, for example, a particularly close parallel can be found in the "Eleusis type" of Asklepios, named after a freestanding statue found at Eleusis and dated to the fourth quarter of the 4th century (Fig. 15). ${ }^{27}$ Like the Demos on the north slope relief, Asklepios stands with his weight on his left leg while his right knee is bent and projects slightly forward. His left arm is completely covered by the himation, and his hand rests on his raised left hip. The triangular overfold of his himation falls diagonally from left to right toward the weight-bearing leg.

While the Asklepios of this type is usually shown leaning on his staff, the right arm of the north slope Demos figure is raised to crown the honorand, resulting in slight differences in the height of the himation on the right side of the body. Similarities between the two male figures also include the ridged folds of their mantles that stretch diagonally from ankle to hip in a manner typical of the third and fourth quarters of the century,
Figure 15. Eleusis, Museum 5100. Marble statue of Asklepios dedicated by Epikrates, son of Pamphilos, from deme of Leukonoion ( $\left.I G \mathrm{II}^{2} 4414\right)$. Fourth quarter of the 4 th century в.c. Courtesy Museum

27. Eleusis, Museum 5100; Adam 1966, pp. 102-104, pls. 50-51; LIMC II, 1984, p. 882, no. 234, pl. 652, s.v. Asklepios (B. Holtzmann). An inscription ( $\left.I G \mathrm{II}^{2} 4414\right)$ records that the statue was dedicated to Asklepios by Epikrates, son of Pamphilos, from the deme of Leukonoion. For the type, see LIMC II, 1984, pp. 882-884, nos. 234260, s.v. Asklepios (B. Holtzmann). 
as well as the lines of folds that radiate in all directions from a central point where the hand rests on the hip. The same rendering of folds can be observed, for example, on document reliefs NM 2986 (Fig. 12) and, with a slight variation in pose, NM 2946 (Fig. 9).

Finally, the head and facial features of the north slope figure, with medium-long hair, full beard, and deep-set eyes, can be compared to another Demos figure on document relief NM 1482 (Fig. 11), datable to $318 / 7$ в.C. All of these factors point to a date in the third to fourth quarter of the 4th century for this previously unpublished fragment of a document relief from the north slope of the Acropolis.

\section{ACKNOWLEDGMENTS}

I would like to record my thanks to the late Oscar Broneer for permission to study the material from his excavations on the north and east slopes of the Acropolis from 1931 to 1939. For photographs of document reliefs and permission to reproduce them here I am grateful to the First and Third Ephoreias of Prehistoric and Classical Archaeology, the National Archaeological Museum, the Epigraphical Museum, the Acropolis $\mathrm{Mu}^{-}$ seum, the Eleusis Museum, the Agora Excavations, the Deutsches Archäologisches Institut, Athens, and, in particular, Alkestis Choremi, Jan Jordan, Nikolaos Kaltsas, Charalambos Kritzas, Michael Krumme, Kalliope Lazaridi, Nelly Lazaridou, Craig Mauzy, Marie Mauzy, Kalliope Papaggeli, Liana Parlama, Rosa Proskynitopoulou, and Christina Vlassopoulou. I would also like to thank Nancy Klein, Carol Lawton, Olga Palagia, Brunilde Ridgway, Peter Schultz, and the editor and anonymous reviewers of Hesperia for advice and many helpful comments. My research in Athens on the north slope material has been made possible by generous grants from Charles Paget and the Edward A. Schrader Endowed Fund for Classical Archaeology at Indiana University. 


\section{APPENDIX \\ DEPICTIONS OF DEMOS ON ATTIC DOCUMENT RELIEFS}

This appendix presents a list of all definite, probable, and possible depictions of Demos on Attic document reliefs currently known to me. I have organized the material first according to "seated" and "standing" types (Table 1), followed by a few reliefs where a Demos-like figure is not actually preserved, but has been conjectured on the basis of other factors, such as the presence of Boule or Athena (Table 2). It should be noted, however, that some of the identifications and restorations are very speculative and may not be accepted by all or even the majority of scholars. The types have also been organized chronologically. Within any quarter century, priority has been given to those reliefs dated by inscription to a specific year, followed by examples dated by sculptural style alone.

Since each of the reliefs has been described in full elsewhere, I present the material in the form of a concordance, providing references to the museum or collection where the relief currently resides, inscription numbers in $I G, S E G$, or $C I G$, the date of the relief, and catalogue numbers in the most recent and thorough studies of Demos, document reliefs, and political personifications in Athenian art. ${ }^{28}$

The tables make clear that the depiction of Demos on Attic document reliefs is primarily a phenomenon of the second half of the 4th century в.c. Although some scholars have suggested that Demos appears on reliefs as early as the last quarter of the 5th century, the earliest monuments for which there is general agreement about the presence of this important political personification date to the middle of the 4th century or shortly before. The majority of monuments, both those firmly dated by inscription and those dated by sculptural style, belong to the third and fourth quarters of the 4th century. As Lawton has suggested, the increased popularity of Demos and other "democratic" personifications in the visual arts of this period may be a response to a combination of artistic, political, philosophical, and even religious factors as Athenian democracy becomes more specialized, more self-conscious, and more threatened by both internal and external forces. ${ }^{29}$ In this way, the appearance of Demos on Attic document reliefs reflects a close relationship between public art and political ideology in 4th-century Athens.
28. The studies referred to in Tables 1 and 2 are as follows. Demos: Palagia 1980; Tzachou-Alexandri = LIMC III, 1986, s.v. Demos. Document reliefs: Meyer 1989; Lawton 1995a. Political personifications: TzachouAlexandri 1994; Smith 1997;

Messerschmidt 2003.

29. Lawton 1993, pp. 15-16; 1995a, p. 31. 
TABLE 1. DEPICTIONS OF DEMOS(?) ON ATTIC DOCUMENT RELIEFS

\begin{tabular}{|c|c|c|c|c|c|c|c|}
\hline $\begin{array}{l}\text { Museum and } \\
\text { Inscription No. }\end{array}$ & Date (B.C.) & Palagia & Tzachou-Alexandri & Meyer & Lawton & Smith & Messerschmidt \\
\hline \multicolumn{8}{|c|}{ Seated Demos(?) } \\
\hline $\begin{array}{l}\text { EM } 7859 \\
I G \mathrm{II}^{2} 1410\end{array}$ & $37 \underline{6} / 5$ & $\begin{array}{l}\text { E1 } \\
\text { "Demos" }\end{array}$ & $\begin{array}{l}71 \\
\text { Demos }\end{array}$ & $\begin{array}{l}\text { A49 } \\
\text { Kekrops }\end{array}$ & $\begin{array}{l}20 \\
\text { probably } \\
\text { Erechtheus }\end{array}$ & - & - \\
\hline $\begin{array}{l}\mathrm{NM} 1467 \\
I G \mathrm{II}^{2} 97\end{array}$ & $375 / 4(?)$ & $\begin{array}{l}\text { E2 } \\
\text { "Demos" }\end{array}$ & $\begin{array}{l}53 \\
\text { Demos }\end{array}$ & $\begin{array}{l}\text { A51 } \\
\text { Demos }\end{array}$ & $\begin{array}{l}96 \\
\text { Zeus }\end{array}$ & $\begin{array}{l}\text { DR12 } \\
\text { Zeus; } \\
\text { Demos } \\
\text { doubtful }\end{array}$ & $\begin{array}{l}\text { D2 } \\
\text { Demos }\end{array}$ \\
\hline $\begin{array}{l}\text { Agora } \\
\text { I } 6524 \\
S E G 12.87\end{array}$ & $337 / \underline{6}$ & $\begin{array}{l}\text { E3 } \\
\text { "Demos" }\end{array}$ & $\begin{array}{l}54 \\
\text { Demos }\end{array}$ & $\begin{array}{l}\text { A97 } \\
\text { Demos }\end{array}$ & $\begin{array}{l}38 \\
\text { Demos }\end{array}$ & $\begin{array}{l}\text { DR41 } \\
\text { probably } \\
\text { Demos }\end{array}$ & $\begin{array}{l}\text { D6 } \\
\text { Demos }\end{array}$ \\
\hline $\begin{array}{l}\mathrm{NM} 2407 \\
I G \mathrm{II}^{2} 4630\end{array}$ & $\begin{array}{l}\text { 3rd quarter } \\
\text { 4th cent. }\end{array}$ & $\begin{array}{l}\text { E4 } \\
\text { Demos }\end{array}$ & $\begin{array}{l}46 \\
\text { Demos }\end{array}$ & $\begin{array}{l}\text { A94 } \\
\text { Demos }\end{array}$ & $\begin{array}{l}133 \\
\text { Demos }\end{array}$ & $\begin{array}{l}\text { DR27 } \\
\text { Demos }\end{array}$ & $\begin{array}{l}\text { D4 } \\
\text { Demos }\end{array}$ \\
\hline EM 2809 & $\begin{array}{l}\text { 2nd half } \\
\text { 4th cent. }\end{array}$ & $\begin{array}{l}\text { E5 } \\
\text { "Demos" }\end{array}$ & $\begin{array}{l}65 \\
\text { Demos }\end{array}$ & $\begin{array}{l}\text { A144 } \\
\text { divinity } \\
\text { (Demos) }\end{array}$ & $\begin{array}{l}167 \\
\text { probably } \\
\text { Demos }\end{array}$ & $\begin{array}{l}\text { DR34 } \\
\text { probably } \\
\text { Demos }\end{array}$ & - \\
\hline \multicolumn{8}{|c|}{ Standing Demos (?) } \\
\hline $\begin{array}{l}\text { Eleusis } \\
\text { E958 (5093) } \\
I G \mathrm{I}^{3} 79\end{array}$ & $42 \underline{2} / 1$ & - & $\begin{array}{l}42 \\
\text { Demos of Eleusis } \\
\text { more likely than } \\
\text { Triptolemos }\end{array}$ & $\begin{array}{l}\text { A5 } \\
\text { Iakchos }\end{array}$ & $\begin{array}{l}3 \\
\text { probably } \\
\text { Triptolemos }\end{array}$ & $\begin{array}{l}\text { DR1 } \\
\text { possibly } \\
\text { Demos of } \\
\text { Eleusis }\end{array}$ & - \\
\hline $\begin{array}{l}\text { Lost. } \\
\text { Formerly } \\
\text { Piraeus } \\
\text { (+ Piraeus } 1595 \\
\left.\quad=I G \mathrm{I}^{3} 136\right)\end{array}$ & $\begin{array}{l}\text { ca. 432- } \\
411(?) \\
(413 / 2 ?)\end{array}$ & - & - & $\begin{array}{l}\text { A12 } \\
\text { man }\end{array}$ & $\begin{array}{l}70 \\
\text { more likely a } \\
\text { mortal } \\
\text { worshiper } \\
\text { or honorand }\end{array}$ & $\begin{array}{l}\text { DR4 } \\
\text { possibly } \\
\text { Demos }\end{array}$ & - \\
\hline $\begin{array}{l}\text { Louvre } \\
\text { MA } 831 \\
I G \mathrm{I}^{3} 375\end{array}$ & $40 \underline{9} / 8$ & $\begin{array}{l}\text { D1 } \\
\text { Kekrops, } \\
\text { Erechtheus, } \\
\text { or Demos }\end{array}$ & $\begin{array}{l}43 \\
\text { probably } \\
\text { Demos }\end{array}$ & $\begin{array}{l}\text { A16 } \\
\text { Demos }\end{array}$ & $\begin{array}{l}8 \\
\text { probably } \\
\text { Erechtheus }\end{array}$ & - & $\begin{array}{l}\text { D1 } \\
\text { Demos }\end{array}$ \\
\hline $\begin{array}{l}\text { NM } 1479 \\
I G \mathrm{II}^{2} 1392\end{array}$ & $39 \underline{7} / 6$ & $\begin{array}{l}\text { D2 } \\
\text { (similar to } \\
\text { D1, above) }\end{array}$ & $\begin{array}{l}44 \\
\text { Demos }\end{array}$ & $\begin{array}{l}\text { A36 } \\
\text { Hephaistos(?) }\end{array}$ & $\begin{array}{l}14 \\
\text { probably } \\
\text { Erechtheus }\end{array}$ & - & - \\
\hline $\begin{array}{c}\text { AM } 2427 \\
+2758\end{array}$ & $\begin{array}{l}\text { 1st quarter } \\
\text { 4th cent. }\end{array}$ & - & - & $\begin{array}{l}\text { A76 } \\
\text { male figure }\end{array}$ & $\begin{array}{l}91 \\
\text { hero }\end{array}$ & $\begin{array}{l}\text { DR11 } \\
\text { possibly } \\
\text { Demos }\end{array}$ & - \\
\hline $\begin{array}{l}\text { EM } 7024 \\
I G \mathrm{II}^{2} 110\end{array}$ & $363 / \underline{2}$ & - & $\begin{array}{l}\text { (Tzachou- } \\
\text { Alexandri } \\
\text { 1994, p. 66) } \\
\text { Demos }\end{array}$ & $\begin{array}{l}\text { A56 } \\
\text { Demos }\end{array}$ & $\begin{array}{l}23 \\
\text { probably } \\
\text { Demos or a } \\
\text { patron deity }\end{array}$ & $\begin{array}{l}\text { DR16 } \\
\text { possibly } \\
\text { Demos or } \\
\text { patron deity }\end{array}$ & $\begin{array}{l}\text { D3 } \\
\text { Demos }\end{array}$ \\
\hline
\end{tabular}


TABLE 1-Continued

\begin{tabular}{|c|c|c|c|c|c|c|c|}
\hline $\begin{array}{l}\text { Museum and } \\
\text { Inscription No. }\end{array}$ & Date (B.C.) & Palagia & Tzachou-Alexandri & Meyer & Lawton & Smith & Messerschmidt \\
\hline $\begin{array}{l}\text { EM } 2796 \\
I G \mathrm{II}^{2} 167\end{array}$ & $\begin{array}{l}\text { 1st half } \\
\text { 4th cent. }\end{array}$ & $\begin{array}{l}\text { D4 } \\
\text { "Demos" }\end{array}$ & $\begin{array}{l}70 \\
\text { Demos }\end{array}$ & $\begin{array}{l}\text { A147 } \\
\text { divinity }\end{array}$ & $\begin{array}{l}110 \\
\text { divinity/party } \\
\text { with which } \\
\text { inscription was } \\
\text { concerned }\end{array}$ & $\begin{array}{l}\text { DR14 } \\
\text { possibly } \\
\text { Demos }\end{array}$ & - \\
\hline EM 2788 & $\begin{array}{l}\text { mid-4th } \\
\text { cent. }\end{array}$ & - & - & - & $\begin{array}{l}115 \\
\text { hero or } \\
\text { possibly Demos }\end{array}$ & $\begin{array}{l}\text { DR21 } \\
\text { possibly } \\
\text { Demos }\end{array}$ & - \\
\hline $\begin{array}{l}\text { EM } 2791 \\
I G I^{2} 160\end{array}$ & $\begin{array}{l}\text { mid-4th } \\
\text { cent. }\end{array}$ & $\begin{array}{l}\text { D9 } \\
\text { Demos }\end{array}$ & $\begin{array}{l}69 \\
\text { Demos }\end{array}$ & $\begin{array}{l}\text { A146 } \\
\text { Demos }\end{array}$ & $\begin{array}{l}117 \\
\text { Demos }\end{array}$ & $\begin{array}{l}\text { DR22 } \\
\text { Demos }\end{array}$ & $\begin{array}{l}\text { D13 } \\
\text { Demos }\end{array}$ \\
\hline $\begin{array}{l}\mathrm{NM} 1471 \\
I G \mathrm{II}^{2} 212\end{array}$ & $347 / \underline{6}$ & - & - & $\begin{array}{l}\text { A88 } \\
\text { Apollonios }\end{array}$ & $\begin{array}{l}35 \\
\text { probably } \\
\text { honorand } \\
\text { Apollonios }\end{array}$ & $\begin{array}{l}\text { D39 } \\
\text { possibly } \\
\text { Demos }\end{array}$ & - \\
\hline NM 2986 & $\begin{array}{l}\text { mid-3rd } \\
\text { quarter } \\
\text { 4th cent. }\end{array}$ & - & $\begin{array}{l}\text { (Tzachou- } \\
\text { Alexandri 1994, } \\
\text { p. 66) Demos }\end{array}$ & - & $\begin{array}{l}123 \\
\text { probably } \\
\text { Zeus }\end{array}$ & $\begin{array}{l}\text { DR30 } \\
\text { possibly } \\
\text { Demos } \\
\text { (or Zeus) }\end{array}$ & - \\
\hline $\begin{array}{l}\text { NM } 2952 \\
+2961\end{array}$ & $\begin{array}{l}\text { mid-3rd } \\
\text { quarter } \\
\text { 4th cent. }\end{array}$ & $\begin{array}{l}\text { D3 } \\
\text { "Demos" }\end{array}$ & $\begin{array}{l}56 \\
\text { Demos }\end{array}$ & A95 & $\begin{array}{l}126 \\
\text { probably } \\
\text { Demos }\end{array}$ & $\begin{array}{l}\text { DR28 } \\
\text { possibly } \\
\text { Demos }\end{array}$ & $\begin{array}{l}\text { D5 } \\
\text { Demos }\end{array}$ \\
\hline $\begin{array}{l}\text { NM } 2985 \\
I G \mathrm{II}^{2} 406\end{array}$ & $\begin{array}{l}\text { 3rd quarter } \\
\text { 4th cent. }\end{array}$ & $\begin{array}{l}\text { D5 } \\
\text { "Demos" }\end{array}$ & $\begin{array}{l}45 \\
\text { Demos }\end{array}$ & $\begin{array}{l}\text { A109 } \\
\text { divinity }\end{array}$ & $\begin{array}{l}132 \\
\text { Demos or, } \\
\text { more probably, } \\
\text { Asklepios }\end{array}$ & $\begin{array}{l}\text { DR29 } \\
\text { possibly } \\
\text { Demos, } \\
\text { probably } \\
\text { Asklepios }\end{array}$ & - \\
\hline NM 2946 & $\begin{array}{l}3 \text { rd-4th } \\
\text { quarter } \\
\text { 4th cent. }\end{array}$ & $\begin{array}{l}\text { D11 } \\
\text { "Demos" }\end{array}$ & $\begin{array}{l}60 \\
\text { Demos }\end{array}$ & $\begin{array}{l}\text { A115 } \\
\text { divinity } \\
\text { (Demos? } \\
\text { Phyle hero?) }\end{array}$ & $\begin{array}{l}149 \\
\text { probably } \\
\text { Demos }\end{array}$ & $\begin{array}{l}\text { DR36 } \\
\text { possibly } \\
\text { Demos }\end{array}$ & $\begin{array}{l}\text { D8 } \\
\text { Demos }\end{array}$ \\
\hline $\begin{array}{l}\text { Agora } \\
\text { AS } 146\end{array}$ & $\begin{array}{l}\text { 3rd-4th } \\
\text { quarter } \\
\text { 4th cent. }\end{array}$ & - & - & - & - & - & - \\
\hline $\begin{array}{l}\text { EM } 7155 \\
I G \mathrm{II}^{2} 347\end{array}$ & $322 / \underline{1}$ & - & $\begin{array}{l}\text { (Tzachou- } \\
\text { Alexandri } \\
\text { 1994, p. 67) } \\
\text { Demos }\end{array}$ & $\begin{array}{l}\text { A103 } \\
\text { Demos }\end{array}$ & $\begin{array}{l}45 \\
\text { probably } \\
\text { Demos }\end{array}$ & $\begin{array}{l}\text { DR43 } \\
\text { possibly } \\
\text { Demos }\end{array}$ & $\begin{array}{l}\text { D7 } \\
\text { Demos }\end{array}$ \\
\hline $\begin{array}{l}\text { Cambridge } \\
\text { Fitzwilliam } \\
\text { GR13.1865 } \\
\text { CIG } 3635\end{array}$ & ca. 330 & - & - & $\begin{array}{l}\text { A81 } \\
\text { Demos(?) }\end{array}$ & $\begin{array}{l}\text { "not Attic” } \\
\text { (p. 3, n. 13) }\end{array}$ & $\begin{array}{l}\text { DR44 } \\
\text { possibly } \\
\text { Demos }\end{array}$ & - \\
\hline
\end{tabular}


TABLE 1-Continued

\begin{tabular}{|c|c|c|c|c|c|c|c|}
\hline $\begin{array}{l}\text { Museum and } \\
\text { Inscription No. }\end{array}$ & Date (B.C.) & Palagia & Tzachou-Alexandri & Meyer & Lawton & Smith & Messerschmidt \\
\hline $\begin{array}{l}\text { Athens, } \\
\text { St. Lydakis } \\
\text { Collection }\end{array}$ & $\begin{array}{l}\text { ca. 330- } \\
320\end{array}$ & - & - & $\begin{array}{l}\text { A119 } \\
\text { Demos }\end{array}$ & $\begin{array}{l}147 \\
\text { probably } \\
\text { Demos of } \\
\text { Acharnai(?) }\end{array}$ & $\begin{array}{l}\text { DR45 } \\
\text { possibly } \\
\text { Demos of } \\
\text { Acharnai(?) }\end{array}$ & ) \\
\hline $\begin{array}{l}\text { Agora } \\
\text { I 4224a+ } \\
4224 b\end{array}$ & $324 / \underline{3}$ & - & - & $\begin{array}{l}\text { A124 } \\
\text { divinity }\end{array}$ & $\begin{array}{l}48 \\
\text { unknown }\end{array}$ & $\begin{array}{l}\text { DR46 } \\
\text { possibly } \\
\text { Demos }\end{array}$ & - \\
\hline $\begin{array}{l}\text { EM } 2811+ \\
7180 \\
I G \mathrm{II}^{2} 367\end{array}$ & $32 \underline{3} / 2$ & $\begin{array}{l}\text { D6 } \\
\text { "Demos" }\end{array}$ & $\begin{array}{l}57 \\
\text { Demos }\end{array}$ & $\begin{array}{l}\text { A125 } \\
\text { Demos }\end{array}$ & $\begin{array}{l}49 \\
\text { almost } \\
\text { certainly } \\
\text { Demos }\end{array}$ & $\begin{array}{l}\text { DR47 } \\
\text { probably } \\
\text { Demos }\end{array}$ & $\begin{array}{l}\text { D9 } \\
\text { Demos }\end{array}$ \\
\hline $\begin{array}{l}\text { NM } 1482 \\
I G I^{2} 448\end{array}$ & $31 \underline{8} / 7$ & $\begin{array}{l}\text { D7 } \\
\text { Zeus Soter } \\
\text { or Demos }\end{array}$ & $\begin{array}{l}58 \\
\text { Demos } \\
\text { more likely } \\
\text { than Zeus }\end{array}$ & $\begin{array}{l}\text { A134 } \\
\text { Demos }\end{array}$ & $\begin{array}{l}54 \\
\text { probably } \\
\text { Demos }\end{array}$ & $\begin{array}{l}\text { DR48 } \\
\text { probably } \\
\text { Demos }\end{array}$ & $\begin{array}{l}\text { D11 } \\
\text { Demos }\end{array}$ \\
\hline $\begin{array}{l}\text { NM } 2958 \\
\text { (+ EM } 7166 \\
=I G \mathrm{II}^{2} 417[\text { ?]) }\end{array}$ & $\begin{array}{l}\text { 4th } \\
\text { quarter } \\
\text { 4th cent. }\end{array}$ & $\begin{array}{l}\text { D8 } \\
\text { "Demos" } \\
\text { (LIMC III, } \\
\text { 1988, p. 120, } \\
\text { s.v. Eutaxia) } \\
\text { Demos or } \\
\text { phyle hero }\end{array}$ & $\begin{array}{l}59 \\
\text { Demos }\end{array}$ & $\begin{array}{l}\text { A142 } \\
\text { divinity } \\
\text { (Demos? } \\
\text { Phyle hero?) }\end{array}$ & $\begin{array}{l}150 \\
\text { more likely } \\
\text { Demos than } \\
\text { phyle hero }\end{array}$ & $\begin{array}{l}\text { DR49 } \\
\text { probably } \\
\text { Demos }\end{array}$ & $\begin{array}{l}\text { D12 } \\
\text { Demos }\end{array}$ \\
\hline NM 2404 & $\begin{array}{l}\text { 2nd half } \\
\text { 4th cent. }\end{array}$ & $\begin{array}{l}\text { D10 } \\
\text { "Demos" }\end{array}$ & $\begin{array}{l}61 \\
\text { Demos }\end{array}$ & $\begin{array}{l}\text { A162 } \\
\text { male } \\
\text { divinity }\end{array}$ & $\begin{array}{l}165 \\
\text { female } \\
\text { divinity } \\
\text { (Kore) }\end{array}$ & $\begin{array}{l}\text { DR35 } \\
\text { male, } \\
\text { possibly } \\
\text { Demos }\end{array}$ & - \\
\hline EM 2798 & $\begin{array}{l}\text { 2nd half } \\
\text { 4th cent. }\end{array}$ & - & - & $\begin{array}{l}\text { A84 } \\
\text { honorand }\end{array}$ & $\begin{array}{l}168 \\
\text { honorand }\end{array}$ & $\begin{array}{l}\text { DR23 } \\
\text { possibly } \\
\text { Demos }\end{array}$ & - \\
\hline AM 7231 & $\begin{array}{l}\text { 2nd half } \\
\text { 4th cent. }\end{array}$ & - & $\begin{array}{l}55 \\
\text { Demos }\end{array}$ & $\begin{array}{l}\text { A138 } \\
\text { divinity }\end{array}$ & $\begin{array}{l}172 \\
\text { probably } \\
\text { Demos }\end{array}$ & $\begin{array}{l}\text { DR33 } \\
\text { probably } \\
\text { Demos }\end{array}$ & $\begin{array}{l}\text { D10 } \\
\text { Demos }\end{array}$ \\
\hline NM 7272 & $\begin{array}{l}\text { 2nd half } \\
\text { 4th cent. }\end{array}$ & - & - & A182 & $\begin{array}{l}176 \\
\text { probably } \\
\text { Demos of } \\
\text { Aixone(?) }\end{array}$ & $\begin{array}{l}\text { DR38 } \\
\text { Demos, } \\
\text { perhaps of } \\
\text { Aixone(?) }\end{array}$ & - \\
\hline
\end{tabular}

$\mathrm{AM}=$ Acropolis Museum; $\mathrm{EM}=$ Epigraphical Museum; NM = Athens, National Museum. For citations, see n. 28. 
TABLE 2. DEMOS NOT PRESERVED, BUT CONJECTURED

\begin{tabular}{|c|c|c|c|c|c|c|c|}
\hline Museum No. & Date (B.C.) & Palagia & Tzachou-Alexandri & Meyer & Lawton & Smith & Messerschmidt \\
\hline NM 1473 & $\begin{array}{l}\text { 3rd quarter } \\
4 \text { th cent. }\end{array}$ & - & $\begin{array}{l}\text { (Tzachou-Alexandri } \\
\text { 1994, p. 56) mortal }\end{array}$ & A136 & $\begin{array}{l}142 \\
\text { almost certainly } \\
\text { Demos }\end{array}$ & $\begin{array}{l}\text { DR19 } \\
\text { probably } \\
\text { Demos }\end{array}$ & - \\
\hline AM 6787 & $\begin{array}{l}\text { 3rd quarter } \\
\text { 4th cent. }\end{array}$ & - & - & A112 & $\begin{array}{l}134 \\
\text { Demos or honorand's } \\
\text { patron deity likely }\end{array}$ & $\begin{array}{l}\text { DR26 } \\
\text { possibly Demos } \\
\text { or patron deity }\end{array}$ & - \\
\hline AM 3304 & $\begin{array}{l}\text { 2nd half } \\
\text { 4th cent. }\end{array}$ & - & - & A174 & $\begin{array}{l}163 \\
\text { Athena or Demos } \\
\text { likely }\end{array}$ & $\begin{array}{l}\text { DR32 } \\
\text { probably Athena } \\
\text { or Demos }\end{array}$ & a \\
\hline
\end{tabular}

$\mathrm{AM}=$ Acropolis Museum; NM = Athens, National Museum. For citations, see n. 28.

\section{REFERENCES}

Adam, S. 1966. The Technique of Greek Sculpture, London.

Agora $=$ The Athenian Agora, Princeton

$\mathrm{III}=\mathrm{R}$. E. Wycherley, The Literary and Epigraphical Testimonia, 1957.

$\mathrm{XIV}=\mathrm{H}$. A. Thompson and R. E. Wycherley, The Agora of Athens: The History, Shape, and Uses of an Ancient City Center, 1972.

Broneer, O. 1938a. "Excavations on the North Slope of the Acropolis, 1937," Hesperia 7, pp. 161-263.

- 1938b. "Recent Discoveries on the North Slope of the Acropolis in Athens," AJA 42, pp. 161-164.

_. 1939. "A Mycenaean Fountain on the Athenian Acropolis," Hesperia 8, pp. 317-433.

Hamdorf, F. 1964. Griechische Kultspersonifikationen der vorbellenistischen Zeit, Mainz.

Kron, U. 1979. "Demos, Pnyx, und Nympenhugel: Zu Demos-Darstellungen und zum ältesten Kultort des Demos in Athen," AM94, pp. $49-75$.

Lawton, C. 1993. "Representations of Athenian Democracy in Attic Document Reliefs," in The Birth of Democracy: An Exhibition Celebrating the 2500th Anniversary of Democracy at the National Archives, Washington, D.C., June 15, 1993-January 2, 1994, ed. J. Ober and C.W. Hedrick, Athens, pp. 12-16.

. 1995a. Attic Document Reliefs: Art and Politics in Ancient Athens, Oxford.

—. 1995b. "Four Document Reliefs from the Athenian Agora," Hesperia 64, pp. 121-130.

Meritt, B. D. 1952. "Greek Inscriptions," Hesperia 21, pp. 340-380.

Messerschmidt, W. 2003. PROSOPOPOILA: Personifikationen politischen Charakters in spätklassischer und hellenistischer Kunst (Arbeiten zur Archäologie), Cologne.
Meyer, M. 1989. Die griechischen Urkundenreliefs (AM-BH 13), Berlin.

Palagia, O. 1980. Euphranor, Leiden.

Raubitschek, A. E. 1962. "Demokratia," Hesperia 31, pp. 238-243.

Rumpf, A. 1951. "Parrhasios," AJA 55, pp. 1-12.

Smith, A. 1997. "Political Personifications in Classical Art” (diss. Yale Univ.).

Tzachou-Alexandri, O. 1993. "Personifications of Democracy," in The Birth of Democracy: An Exhibition Celebrating the 2500th Anniversary of Democracy at the National Archives, Washington, D.C., June 15, 1993-January 2, 1994, ed. J. Ober and C. W. Hedrick, Athens, pp. 149-155.

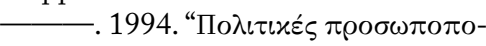

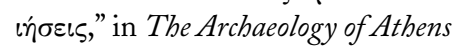
and Attica under the Democracy, ed. W. D. E. Coulson, O. Palagia, T. L. Shear Jr., H. A. Shapiro, and F. J. Frost, Oxford, pp. 55-72.

\section{Kevin Glowacki}

\author{
INDIANA UNIVERSITY \\ DEPARTMENT OF CLASSICAL STUDIES \\ 547 BALLANTINE HALL \\ IO 20 EAST KIRKWOOD AVENUE \\ BLOOMINGTON, INDIANA 47405 \\ kglowack@indiana.edu
}

\author{
American School of Clasical Studies \\ at Athens \\ 54 SOUIDIAS STREET \\ IO6-76 ATHENS \\ GREECE
}

kglowack@ascsa.edu.gr 